\title{
Towards a New Vision of International Terrorism
}

\author{
Assistant Professor Dr. Najdat Sabri Ismail ${ }^{*}$
}

Keywords: Terrorism, Terrorist Groups, Violence, Political Process. https://doi.org/10.31271/jopss.10013

\begin{abstract}
An article presented to the Faculty of Political Science and Journalism - University of Adam Mickiewicz - Poland, in the framework of the second academic conference of the Faculty under the title (Beyond Europe), which included many topics (Methodology of Political Science and International Relations, Global Terrorism and Asymmetrical Challenges, democracy, globalization, international economic relations, International Conflicts, Geopolitics and Natural, US-EU-China Between Economic Cooperation and Rivalry, MENA Region and its Contemporary Dynamics, Belt and Road Initiative (BRI) Regional and Global Perspectives and Challenges), during 24th to 25th October 2018, in the Polish city of Poznan **
\end{abstract}

In 1972, the United Nations set up a special committee to study the causes of terrorism. According to the report, the main causes were hunger, poverty, unemployment, alienation, marginalization, racist policies towards the peoples of Asia, Africa and Latin America, social and economic injustices, lack of respect for human rights and democracy, and lack of respect for the principle of self-determination.

More than 40 years after this report, studies of terrorist events indicate that the understanding of terrorism is relative and not absolute. There are divergent

\footnotetext{
* Assistant Professor and General Director of the Directorate of Research and Development at the Ministry of Higher Education and Scientific Research in the Kurdistan Regional Government Iraq.

najdat.aqraey@mhe-krg.org

** Beyond Europe, Faculty of Political Science and Journalism at Adam Mickiewicz University, Poznan, 23rd - 24th October 2018, available at:

http://beyondeurope.amu.edu.pl/

https://drive.google.com/file/d/1NuHOlmXRWJDw7Ng0ubNARUgXXV-PkNfo/view
} 
views on this subject, from the definition of terrorism to its causes and consequences.

This phenomenon is characterized by multiple mechanisms: intelligence work, the incubator environment, political, economic and social aspects, and new factors related to religious and national intolerance and sectarian extremism.

The wave of terrorism varied from national terrorism to left-wing ideological terrorism or revolutionary violence. In the contemporary world, some terrorist actions can be related to religious aspects, especially after the events of September 11th, 2001 which divided the world into two fronts, i.e., a front against terror and a terror front. Military confrontation against terrorism has already started in many countries (North Africa, Afghanistan, Iraq, Egypt, Indonesia, Nigeria, Gulf countries, Syria, Yemen).

In Europe and as a result of terrorist acts, the policies of these countries have changed to include violent security precautions. Many mechanisms have been utilized to limit the phenomenon. At the same time the international, regional, and internal arenas do witness coalitions in order to confront terrorism. It is possible to say that the terrorism phenomenon has been reduced due to political, security, social and economic actions, yet its causes still exist.

We believe that the main reasons for this phenomenon in today's world are the lack of realistic and clear policy of social peace and the lack of recourse to democratic mechanisms in national public policy, as well as international and regional responsibility in this field.

There have been attempts at reconciliation and dialogue in some countries and the involvement of these terrorist groups in the democratic political process, but in many other countries, the harsh policy of military confrontation and the laws against terrorism focused only on punitive penal aspects. The anti-terrorism laws all over the world generally lack the consideration of other aspects of softer aspects of treatment.

We believe that terrorism is about the struggle for power and wealth, so governments and terrorist groups must move towards dialogue, and both sides 
must understand each other with a realistic policy and responsibility, and in the end, respect the views of both parties for reaching a result to solve the problem.

It is wrong to think that terrorists have one unified policy. No, they have differing organizations, capital, resources, an incubating environment, the ability to confront, and dormant cells that, when needed, carry out their tasks.

They have been to move from small meetings to violent operations, to declare themselves in entities that take the land. This phenomenon must be reexamined. It is wrong to believe that the collection of intelligence and security information and the military strike are enough to eliminate the terrorist phenomenon. It is also wrong to confine the issue of terrorism only to Islamic jihadists. They are only a fraction of international terrorist groups working to control power and wealth.

We believe that America and its allies cannot alone eradicate the terrorist phenomenon, but we must study the psychology of the areas that harbour terrorism, respect the customs and traditions, and work to improve the living standards of those areas.

The world today has a great ethical responsibility to review anti-terrorism policies, especially those related to security, intelligence, military or punitive laws in the form of terrorism in national security policies, especially in the fields of research, security and intelligence, a military strike. The steps should be at the level of national security policies, particularly those related to dialogue, the possibilities of being unarmed, ethnic treatment and social peace on the foundations of democracy and human rights.

It should be noted that there is a direct link between terrorism and corruption in societies. Corruption helps to create an environment conducive to terrorism. Such a new perspective indicates that those involved in corruption carry out terrorist acts for the purpose of eliminating each other.

The drug, human, and weapons traffickers are involved with political traders in the fields of organized crime and money laundering. Terrorist groups are involved with them. Such trade is considered one of the financial sources of terrorist groups. 
To sum up the above, and according to this analytical study of the terrorist phenomenon, we ask about the future of terrorism treatment. The use of dialogue and responsible reconciliation, justice and accountability, disarmament, non-violence, review of terrorism legislation, and sitting at the negotiating table are all mechanisms to deal with terrorism.

The experience of the Israelis with the Palestinians on the basis of coexistence is considerable. The Palestinian groups (terrorist in Israel's eyes) engaged for a long time with the Israel dialogue groups in peaceful dialogue and have been living together in such an atmosphere. The experiences of Sri Lanka, Turkey, Darfur and Kashmir have been unsuccessful. The experience ranges from success to failure in Afghanistan and the question is about the situation in Iraq.

Terrorist activities against the US and international powers began in Iraq after the 2003 invasion. This is the date of the entry of the American and British forces into Iraq.

Terrorism is characterized by violence. The groups have multiplied from resistance to a militant military organization to a preacher as an organization that declares the state of the caliphate and holds the land and governs according to its ideology. A kind of consensus exists on the international and regional military and security confrontation with terrorism.

The deal is still appropriate at the level of military and legal confrontation and must be reviewed and re-read the possibilities of dialogue is one of the noble humanitarian attempts and at the same time must be held accountable for tainted hands blood.

In addition to the international military and security alliances, the world has witnessed, since the middle of the last century, a number of selective international agreements in the face of international terrorism (the 1963 Tokyo convention on other crimes and acts committed on board aircraft),(convention for the suppression of unlawful seizure of aircraft signed at Hague in December 1970) (Convention for the Suppression of Unlawful Acts against the Safety of Civil Aviation 1071),(convention for the suppression of unlawful seizure of 
aircraft \{Hijacking Conventional\}, entered into force Oct. 14, 1971), ( International convention against the taking of hostages New York, 17 December 1979), (International Convention for the Suppression of the Financing of Terrorism adopted by the General assembly of the United Nation in resolution 54/109 of 9 December 1999).

A number of UN Security Council resolutions on international terrorism were issued, notably the UN security resolution 1373 (2001) following the September $11^{\text {th }}$ attacks, which stressed that international terrorism should be considered as an international crime. The exchange of information, the lack of a safe haven and the provision of justice, judicial assistance and effective security measures.

And what is generally observed in such efforts is not properly addressing the fundamental problem related to the definition of the terrorist situation, but only describe the situation, and also noted the selectivity and partial in the confrontation, and free of the aspects related to the treatment of intellectual and dialogue and restorative and review, and its focus, as in the case of national legislation, is on the harsh penal aspects of treatment, and therefore it has not been able to eliminate international terrorism, and the result has been scaling.

The world today needs an international agreement to combat international terrorism that is comprehensive and deals with the definition of international terrorism. It should regulate the obligations of parties to the agreement to cooperate in preventing the crime of international terrorism and the obligation to exercise jurisdiction and obligation to extradite persons to whom international terrorism is attributed.in the proposed agreement to guarantee the rights of persons to whom international terrorism is attributed, as well as matters relating to the interpretation of the Convention and the mechanisms of its application. 
